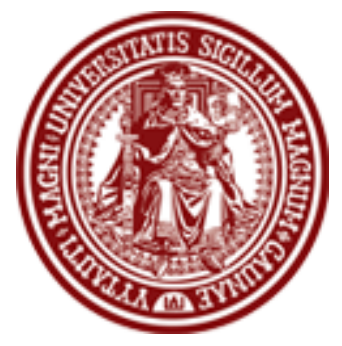

BALTIC JOURNAL OF LAW \& POLITICS

VOLUME 6, NUMBER 1 (2013)

ISSN 2029-0454

http://www.degruyter.com/view/j/bjlp

Cit.: Baltic Journal of Law \& Politics 6:1 (2013): 163-180

DOI: $10.2478 / \mathrm{bjlp}-2013-0008$

\title{
THE ROLE OF SCIENTISTS IN LITHUANIAN ENERGY SECURITY DISCOURSE FORMATION
}

\author{
Dainius Genys \\ Associate Professor; Researcher \\ Energy Security Research Centre, Vytautas Magnus University (Lithuania) \\ Contact information \\ Address: K. Donelaicio 52-114, LT-44244 Kaunas, Lithuania \\ Phone: +370 37327829 \\ E-mail address: d.genys@estc.vdu.It
}

Received: June 7, 2013; reviews: 2; accepted: July 31, 2013.

\section{ABSTRACT}

The aim of the article is to investigate the participation of scientists in the energy security discourse. The empirical research was carried out on the basis of qualitative access while conducting semi-structured interviews with representatives from different branches of science. As the results of the analysis show, despite the strained relations between scientific knowledge and power, Lithuanian scientists do not succeed in converting scientific knowledge into power. Even though scientists have enough knowledge, it is not transformed into power relations due to an existing specific context and the passive role of scientists themselves. Emerging decision-makers' efforts to eliminate scientists from Lithuanian energy security discourse formation pushes the latter into the vague situation in which it is difficult to expand their share of expectations.

Analyses of the scientific discourse show that scientists interpret the energy events in a broader context: while analysing the processes and specific projects that seek to improve energy security, they notice a more comprehensive view and manage to identify advantages, disadvantages and uncertainties of the latter. While marking out the peculiarities of energy security discourse, it may be claimed that the role of the scientists is not significant; realizing the development of energy system there has not created an institutional mechanism for 
scientific expertise; scientists are not being involved and they do not rush to participate in the formation of energy security discourse. They equate the distribution of information with the publishing of knowledge in the scientific world.

\section{KEYWORDS}

Scientific research, Lithuania's energy security, discourse formation, discourse representation

\section{NOTE}

The article is written as a part of a project "Comparative assessment of energy security in Lithuania and Belarus"; the study was funded by the Research Council of Lithuania (project No. MP-010/2011). 


\section{INTRODUCTION}

From a sociological point of view, energy security discourse is a socially constructed entity, involving many various actors in its formation. The access of the sociology of risk investigates how and why a social actor acts in a particular situation. Objective reality, for instance, as an energy security level, does not directly determine the feeling or behaviour of people (e.g. to risk or not to risk), because it depends on the extent to which people perceive the risk of their actions and the environmental risk. Recent surveys (as well as the referendum) present the changing attitude of Lithuanian society towards energy security, although the objective risk remains the same. ${ }^{1}$

The definition of risk arises not only from the threats of objective reality, but also from their presentation and interpretation in society. This subjective risk construction component relates to the definition of the risk to power relations. ${ }^{2}$ Thus, energy security identification is also an object of competition among the many energy security discourse actors, who do not only have different goals, but also have different possibilities to form this discourse while identifying risks and threats in their own way. Intensive competition as well as an inability to agree on and reach a unanimous compromise atomize energy security discourse, and thus prevent it from increasing the objective state of energy security.

In every society, discourse formation takes place in its own way, using various formation procedures, restraining or, on the contrary, enabling discourse power. The formation of Lithuanian energy security discourse is related not only to energy supply and energy system reliability issues, but more and more interest is paid to the influence of energetics on the development of more harmonious society. ${ }^{3}$ Usually, in order to achieve this aim, numerous state forces are mobilized, especially the scientific approach that rationalises and reasonably forecasts the scenario of prospective energy system development. Meanwhile, in Lithuania, it has been repeatedly noted that the issue of energy security is quite politicized. ${ }^{4}$

\footnotetext{
${ }^{1}$ In May 2012 the number of supporting and non supporting NPP was similar (Apklausa: VAI šalininku ir priešininku yra beveik po lygiai (Survey: VNPP Supporters and Opponents Are Almost Equal)) // http://klaipeda.diena.It/naujienos/ekonomika/apklausa-vae-salininku-ir-priesininku-yra-beveik-po-lygiai428441\#axzz2AJ7Ld26A (accessed June 12, 2013)). Meanwhile, in autumn of the same year 62.68 per cent of citizens participated in a referendum that voted against the construction of a new nuclear power plant.

${ }^{2}$ Ulrich Beck, "Living in the World Risk Society," Economy and Society Vol. 35, No. 3 (2006).

${ }^{3}$ Augutis Juozas, Ričardas Krikštolaitis, Dainius Genys, and Giedrius Česnakas, eds., Lietuvos energetinis saugumas. Metinè apžvalga. 2011-2012 (Kaunas: Vytautas Magnus University, 2013).

${ }^{4}$ Arūnas Molis, Lietuvos geoenergetinio saugumo politikos gairès ir Lietuvos geoenergetiniu alternatyvu paieškos trumpuoju ir vidutiniu laikotarpiu (Vilnius: Center for Strategic Studies, 2006); Rasa Baločkaitè and Leonardas Rinkevičius, "Branduolinès energetikos diskursai Lietuvos žiniasklaidoje ir viešojoje nuomoneje: nuostatu takoskyros ir 'kalbančiuju klasės' formavimasis rizikos visuomenèje," Filosofija. Sociologija Vol. 20, No. 4 (2009); Tomas Janeliūnas, "Lithuanian Energy Strategy and its Implications on
} 
Lately, a confrontation between politicians and scientists (particularly energy experts) has emerged. This is evidenced by the fact that the Lithuanian Energy Institute for the first time since 1994, did not participate in preparing the country's energy strategy. ${ }^{5}$ Finally, the scientists themselves speak publicly about disregard for their opinions. ${ }^{6}$ Thus, despite the growing public awareness of the country's energy security problems, lack of communication and inability to reach a unanimous compromise between different actors in formation of the energy security discourse still remain. In order to explain the changing place of science in energy security discourse, the aim of this article is to investigate the participation of scientists in energy security discourse, i.e. to discuss the relevance and efficacy of scientific discourse for matters of public discussions and governance. The empirical study was carried out on the basis of qualitative interviews. ${ }^{7}$ The following features of scientific discourse were analysed in the study: self-sufficiency, stability, dynamism, initiative and feasibility aspects, as well as context of discourse circulation and scientists' way of speaking about energy security. Meanwhile, relevant and stimulating academic curiosity issues such as the extent or prevalence of opposition between politicians and scientists (e.g. in what social groups what "truth" is stronger, and so on), or the extent of the scientific discourse, are left for further studies (which require a different research approach).

\section{THE ROLE OF SCIENCE IN ENERGY SECURITY DISCOURSE}

\section{FORMATION}

On the one hand, the main modern institutions, such as science, business, and politics, which should ensure rationality and safety, face situations that they cannot explain. As the world changes, so too is the interpretation of the latter: from

Regional Cooperation": 190-222; in: Andris Sprūds and Toms Rostoks, eds., Energy: Pulling the Baltic Sea Region together or apart? (Riga: Zinatne, 2009); Dainius Genys and Eigintas Aleksandravičius, "Bendro vardiklio beieškant - Lietuvos energetinio saugumo orientyrai ekspertiniu požiūriu," Politikos moksly almanachas No. 12 (2012).

5 Ministry of Energy of the Republic of Lithuania, The National Energy Independence Strategy (Vilnius, 2012).

6 See websites: http://verslas.delfi.It/energetika/jvilemas-atomine-energetika-lietuvoje-beveik-kaipkrepsinis.d?id=50049544; http://www.zaliojipolitika.It/r-kuodis-be-modelio-retam-politikui-energetiniaiprojektai-telpa-galvoje/.

7 A qualitative semi-structured interview method was used in the study. The interview was conducted in two stages, the first on 1-8 May 2011 (average duration of about $55 \mathrm{~min}$.); the second on 4-15 October 2012 (average duration of about $50 \mathrm{~min}$.). The main criteria for selecting informants: work experience in the field of energy and knowledge of energy security issues. In order to ensure a holistic approach to the problem in question representatives of different disciplines interested in different energy security aspects (representatives of technology, energy, international relations and political science, economics, social science) were questioned, totaling 17 scientists. In order to maintain confidentiality of informants, their names are not mentioned, the workplace is not indicated, they are assigned a code name (e.g. Scientist 1 , etc.), but the experience in the energy research field and represented field (e.g. an economist with 10 years of experience) are indicated. 
winning confidence to causing suspicion. They are no longer risk management tools as they have become sources of risk themselves. ${ }^{8}$

On the other hand, despite the criticism of science for failing to predict or control various forms of risk, while analysing and explaining reality science is still associated with rationality, precision and accuracy. The role of science is particularly important in the energy sector: technologies and their efficiency, reliability as well as long-term effects, usually result from the latest scientific discoveries. Finally, the functioning of the energy system is also measured on the basis of scientific research.

In Lithuania, at least in the context of energy, science has been related with a reliable possibility to ensure the country's energy security for a long time. ${ }^{9}$ While analysing the energy system and crystallizing future perspectives, the arguments of scientists were the most important. In this context, the claim of J.F. Lyotard ${ }^{10}$ that science has always been on the side of power, but nowadays there is a need to rethink the scientific mission, eloquently describes the Lithuanian context. On the one hand, the shift in scientific significance in Lithuania arises from global processes when the results of scientific research often contradict each other, or even deny the previous data, and it partially devalues scientific discoveries and brings in scepticism in a public attitude. On the other hand, a contextual aspect for Lithuania is that there are no developed mechanisms through which scientific expertise could be integrated into the political agenda and decision-making.

Each discourse is the construction of reality (concepts, values, cultural events, etc.). Energy security discourse is not an exception. According to M. Foucault, "every society monitors, makes a selection, organizes and redistributes discourse production, carrying everything out at the same time and involving several procedures that have to subdue the power and threats of discourse, to control the unpredictability of the event, to avoid its difficult, frightening materiality. ${ }^{11}$ The establishment of the Ministry of Energy in Lithuania was related with the aim to ensure the satisfaction of energy users' long-term goals, ${ }^{12}$ and also with a coherent creation of state energy discourse. It was believed that the emergence of such a ministry would provide the opportunity to optimize the forces of the energy policy and as a result a formed systematicity and consistency would allow proper preparation and the ability to deal effectively with threats rising in the energy

\footnotetext{
${ }^{8}$ Ulrich Beck, supra note 2: 336.

${ }^{9}$ Aistè Balžekienè, Socialinis branduolinès rizikos suvokimas: teorinès ižvalgos ir ju refleksija Lietuvos visuomenés požiūriuose i Ignalinos AE, Ph.D. thesis (Kaunas: Kaunas University of Technology, 2006); Vladas Gaidys and Leonardas Rinkevičius, "Černobylio baimè, pigios energijos nauda ar kai kas daugiau? Dvidešimties metu visuomenės nuomonès apie Ignalinos AE sociologiniai tyrimai Lietuvoje," Filosofija. Sociologija Vol. 19, No. 4 (2008): 102-111; Rasa Baločkaitè and Leonardas Rinkevičius, supra note 4.

${ }^{10}$ Francois J. Lyotard, Postmodernus būvis (Vilnius: Baltos lankos, 1993).

${ }^{11}$ Michel Foucault, Diskurso tvarka (Vilnius: Baltos lankos, 1998), p. 7.

12 See webpage: www.enmin.It/It/activity/.
} 
sector. However, every new discourse confronts and is confronted by other discourses and it is forced to compete for legitimization and recognition. While seeking this recognition, discourse creation is not enough; there is a need to maintain a constant discussion, which would help to convince the society of the necessity and benefits of its existence.

In the social sciences the definition of discourse is expanded, emphasizing the concept of discourse as a social action or a particular interaction. ${ }^{13}$ Here, for discourse analysis not only the text is important, but also the actors who are creating, transmitting and interpreting it. In this case, scientists have a duty not only to enrich knowledge and represent it, but also to convey a complex scientific language for society in simple and understandable terms, to convince them with reasonableness of the scientific arguments. Discourse circulation context is no less important and it can accordingly empower or restrict the latter. For instance, institutionalized procedures integrating scientific approach for the creation of country's energy security discourse would significantly enable it, while the indifference of official institutions for science or even efforts to eliminate it, force science not only to accumulate knowledge (to form scientific energy security discourse), but also to compete with other discourses (e.g. political, technocratic, populist, etc.) for recognition and legitimacy.

To paraphrase P. Bourdieu ${ }^{14}$, it seems that the symbolic capital of scientists gives a capacity "to form reality"-in this case, the energy security discourse. The group of scientists is not homogeneous, and therefore there is also an internal competition for power positions (e.g. among scientists from energetics, economics, politics and so on.). Actors (no matter whether it regards to the institution or an individual scientist) who are involved in this process and seek to entrench themselves in predominant positions, when disposing symbolical capital, pursue the symbolical fights for the formation of this reality. Thus, energy security discourse is the subject for competition, which is a permanent struggle, and its structure is not rigid; it is constantly changing, and it is defined by the changing power relations between the discourse actors.

Each discourse depends on its actors' goals and performance. According to Foucault $\mathrm{t}^{15}$, discourse establishes that truth, which is protected by it (there would not be particular truth without particular discourse). Participation of scientists in the energy security discourse is associated with rationality, probabilistic risk

13 Teun A. van Dijk, "Discourse, Ideology and Context," Paper for the $7^{\text {th }}$ International Conference of Pragmatics, Budapest (July 2000), Folia Linguistica XXX/1-2 (2001); Teun A. van Dijk, Discourse and Power (New York: Palgrave Macmillan, 2008); Audronè Telešienè, "Kritiškosios diskurso analizès metodologiniu principu taikymas sociologiniuose tyrimuose, "Filosofija. Sociologija Vol. 16, No. 2 (2005).

${ }_{14}$ Pierre Bourdieu, "Social Space and Symbolic Power," Sociological Theory Vol. 7, No. 1 (1989).

15 Michel Foucault, supra note 11. 
assessment, identification of the most serious threats. An actor's role is important when forming the discourse, because, paraphrasing Foucault, discourse is the environment (conditions) of individual expression, rather than the result. Thus, the reflection of science in the country's energy security discourse is directly related to how actively, enthusiastically and effectively scientists operate in this field and what goals they have set for themselves.

\section{THE PECUliarities OF the ROLE PLAYEd By LithuANian SCIENCE IN ENERGY SECURITY DISCOURSE FORMATION}

In order to understand the nature, dynamics and processes of the energy security discourse, it is not sufficient to analyze the texts or the circumstances of their occurrence. The power of each discourse depends not only on the activity of development and successful persuasion of its legitimacy or its importance, as already mentioned; it is also worth focusing on empowering or limiting of the circulation context of the discourse. J. F. Lyotard ${ }^{16}$ and M. Foucault's ${ }^{17}$ insights, linking knowledge with power, raise a presumption of exceptional scientific positions (resulting from the disposal of scientific knowledge) and a certain a priori share of power in any area of decision-making. The stories of the scientists show that although they have loads of knowledge, due to the specific political context (which is based on prioritizing of the interests of political elite and economic interests groups), and partly due to their own relatively passive role, this knowledge is not transformed into power relations. All this leads to the point that the scientists cannot boast about a special power in energy security discourse:

- "Nowadays, scientific arguments are not welcome, they are not interesting. At least, I think so. The government follows the political and economic benefits." Scientist 15, a political scientist, experience approximately 15 years.

- $\quad$ "When a new law of renewable energy was being created, the opinion of scientists in many cases was left behind the adoption of the law here." Scientist 13 , an energy specialist, experience approximately 10 years.

- If to talk about the government structures, there are national scientific programs initiated. $\langle\ldots\rangle$ we have an opportunity to carry out research and publish its results, to spread its results about the level of energy security. <...> we are heard, but the publicity could be better, of cause, and, and, let's say, involvement as well ...." Scientist 6, a sociologist, experience approximately 10 years.

\footnotetext{
${ }^{16}$ Francois J. Lyotard, supra note 10.

${ }^{17}$ Michel Foucault, Disciplinuoti ir bausti. Kalèjimo gimimas (Vilnius: Baltos lankos, 1998).
} 
- "The opinion of scientists is completely or almost irrelevant to the politicians, because, as I said, partners and personal interests are more important. The majority of people also ignore the scientific arguments, they are more guided by sympathy, dislikes and personal experience. Scientists' opinions are often ignored, as even the same scientists do not agree on some issues either (for objective or subjective reasons)." Scientist 14, an economist, experience approximately 20 years.

As the evidence demonstrates, the participation of Lithuanian scientists in energy security discourse is highly dependent on the more general context. The application of the discourse actors' strategies and peer interactions (in order to represent and legitimate the interests they represent) depend not only on the activities of the scientists themselves (which will be discussed more further), but also on the political context, which in this case limits the scientific discourse on energy security vitality. Scientists miss the mechanisms through which scientific knowledge can be more closely associated with the decisions to be accepted. Even the discoveries of the country's most prestigious analytical centres do not always receive the attention using the results in practice. The informants mentioned that such analytical centres ("think tank") in the other countries (e.g. Germany, Poland, etc.) have a much greater impact than in Lithuania. However, to assess science's influence on decision-making in the energy field is difficult because, in many cases, energy system (infrastructure) development is associated with scientific discoveries. But when we talk about trends in the use of scientific insights in the analysis of strategic energy system development or when measuring the country's energy security, scientists have talked about the more prominent role science used to play.

In the formation of Lithuania's energy security discourse a special role in determining the role of science goes to the Ministry of Energy of the Republic of Lithuania, which is a major actor of Lithuanian energy policy formation and implementation, legitimizing or delegitimizing scientists' activity and setting out specific functions. For example, as previously mentioned, the Lithuanian Energy Institute, one of Lithuania's most important energy research centres of excellence and an expert on energy policy implementation, lost its status, because the Ministry of Energy does not entrust anyone or anything else with the role of expert (or any other more important status). ${ }^{18}$ Despite the dim or episodic scientific collaboration

\footnotetext{
${ }^{18}$ In this case, the reasons why scientists are not involved in the decision-making processes are not so important (whether this is related to the competence, e.g. how much the country's scientists actually know about the energy issues?, or with their subjectivity and interest, such as how many and which of the country's scientists are indeed independent of some interest? By the way, these questions were mentioned by informants themselves), but the fact that there is a lack of cooperation remains. On the other hand, individual scientists manage to get into this process because they are affiliated to certain state agencies and participate in the formation of energy policy as their employees. Thus the real
} 
with the country's official organizations, their role remains important in scientific research, enhancing knowledge about the country's energy system performance and, thus, forming the scientific discourse on energy security.

A separate environment which was mentioned by informants is created for the participation of scientists in energy security discourse; these are research programmes set up by Lithuanian Science Council (e.g. Social Challenges of National Security, Future Energetic) in order to promote research and increase the scientific knowledge in the energy sector. This is undoubtedly one of the most important aspects with regard to scientific discourse. By assessing scientific discourse in the wider context (in particular, its ability to form the political agenda and its implementation), it must be assumed that in such a way scientists are exclusively guided towards the development of science and, thus, retracted (or diverted) from participation in the national energy security discourse. This is partly supported by numerous examples mentioned by the informants about "boringness" and "unnecessity" of scientific knowledge and reasoning as well as limited ability to actually affect the energy policy. This raises another assumption that there are quite good conditions in Lithuania to increase scientific knowledge about energy problems; but despite this growing awareness, it is not practically used in decisionmaking for the development of energy system.

\section{SCIENTISTS' STRATEGIES IN THE FORMATION OF THE ENERGY SECURITY DISCOURSE}

According to P. Bourdieu ${ }^{19}$, the struggle for symbolic power can go in two directions: the first strategy is related with manipulation of the individual position in social space when demonstrating the power to change it and to establish a symbolic presence. This strategy is related with the increase of scientific prestige and importance. Having strengthened their own position the scientists could expect a greater role in the formation of national energy security discourse.

While analysing the forces of scientists who are researching one or other questions of Lithuanian energy security, the growing number of actors involved in this activity have been noted. Those include: VMU (It. VDU) and LEI Energy Security Research Centre, Energy Security Centre under the Ministry of Foreign Affairs of the Republic of Lithuania (It. URM) which has already become the NATO Centre of Energy Security Competences. The Lithuanian Free Market Institute (It. LLRI) also performs calculations related to the energy sector. Long acting 
researchers' forces, concentrated in Vilnius University Institute of International Relations and Political Science (It. TSPMI), as well as Energy Technology Institute at Kaunas University of Technology, also deserve mention The main research centrethe Lithuanian Energy Institute (It. LEI)-deserves special attention as its scientists, in developing various researches on country's energy system assessment, have gained huge competence and experience. Finally, besides the institutionalized energy security researchers' forces there also exist informal, collective or individual forces of researchers (e.g. concentrated in Kaunas University of Technology, Vilnius Gediminas Technical University) which, while realizing individual or group scientific research and publishing data, also mark their position in the symbolic space of energy security discourse formation.

A growing number of scientists should increase competition for symbolic domination and consolidation of the authority not only among themselves but also with other energy security discourse actors. Quantitative and qualitative growth of scientists should allow hope for a more expressive and significant role for scientists' involvement in this discourse formation. This could lead to the formation of a critical majority which would look after more favourable positions for scientists. However, a reduced position for science in the country's energy security discourse would determine that scientists do not equally struggle with other discourse actors (e.g. politicians, various state officials and interest groups) for power positions. In many cases, scientists' competition, when changing their position in the space of discourse formation, leans against a "glass ceiling", which refers to the usage level of scientific arguments in the country's energy policy. All this determines that this strategy becomes inadequate and, due to previously mentioned restrictions, it is revealed only partially, i.e. when scientists of different branches of science compete with each other, not because of a better position in the space of energy security discourse formation in order to empower a scientific attitude, but because of different branches of science arguments applicability when explaining one or other aspects of energy system.

Competition among scientists occurs by providing different arguments and trying to legitimate them, assessing a particular project of energy security. For instance, the VNPP (Visaginas Nuclear Power Plant) project might be a great example of a controversial assessment when scientists, attempting to calculate the benefits of the project, use different methodologies and therefore they come to entirely different results.

- $\quad$ "For me, as an economist, the construction of nuclear-power plant and free market seems to be incompatible, because even though the cost of nucleargenerated electricity will not be competitive, we will have to purchase it. It 
seems incompatible or very expensive things." Scientist 6, an economist, experience approximately 10 years.

- $\quad$ "It is really useful for Lithuania and first of all it useful for me, as a technician, in the sense of ensuring energy security. Then, what concerns the cost, there is no doubt that VNPP is really competitive and it is advisable to implement it." Scientist 9, an energy specialist, experience approximately 7 years.

Competition within the scientific discourse is related to the scientists' attempts to establish the advantages and significance of a represented discipline in the analysis of energy security. It is likely that such a competition, if it is based on openness and consistent reasoning, promotes the formation of energy security discourse, its diversity and makes possible a disclosure of the most optimal measurements conceptions and methodologies of energy security analysis.

The second strategy, with which, according to P. Bourdieu, one can struggle for symbolic power, is an attempt to transform the perception of a category, changing the concepts that form social reality, trying to change the established order to one's own advantage, and eliminating one's values and introducing others. ${ }^{20}$ This strategy is more clearly evidenced not in the struggles between scientists, but in seeking to present the significance and benefit of scientific arguments in a more general discussion on energy security. It is assumed that the development of scientific discourse can rationalize energy policy and help to avoid inefficient decisions and harmful effects if it is taken into account and appropriate decisions are made.

As B. Adam and J. Loon ${ }^{21}$ note, the "reality" of risk depends on its coverage in society, i.e. how it is presented, portrayed, what potential consequences are provided, etc. Without a forceful presentation and continuous escalation, the reality of the risk and potential consequences would remain unclear. Despite the fact that the situation can be objectively safer or without changes, the escalation of constant threat can lead to a different social tension, and vice versa. As previously mentioned, the discourse of scientists is associated with rationality and the deconstruction of existing myths; thus, it can be claimed that the scientific discourse partially objectivises the current situation of energy security. While analysing and verifying various energy security projects with scientific arguments, it is possible to find out the situations which emerge due to the consequences of a current policy.

\footnotetext{
${ }^{20}$ Ibid.

${ }^{21}$ Barbara Adam and Joost van Loon, "Repositioning Risk; the Challenge for Social Theory"; in: Barbara Adam, Ulrich Beck, and Joost Loon, eds., The Risk Society and Beyond (Sage Publications, 2005).
} 
For instance, the aforementioned VNPP in the Energy Independence Strategy ${ }^{22}$ was named as one of the key factors in ensuring Lithuania's energy security. Meanwhile, the opinions of interviewed scientists diverged and they evaluated this project ambiguously. The research has shown that in comparison with the official national energy policy (stated in the mentioned strategy), the scientists, by invoking different methodologies for their own arguments, basically criticized the chosen arguments of politicians and differently assessed VNPP's possible advantages and disadvantages.

- $\quad$ "Lithuania is not able to build Visaginas Nuclear Power Plant (VNPP) and having in mind today's prices of the construction of nuclear power plant, it would be one of the most expensive energy sources. Therefore, there is still no investor (interview had been recorded before the commencement of negotiations with Hitachi - author's note) because in that competitive environment which is now evolving and which is surely to be strong, the cost of nuclear power electricity will be definitely higher than the expected market cost." Scientist 1, an energy specialist, experience approximately 40 years.

- $\quad$ "Talking about energy security, this tucking of all Lithuanian electricity system under "Visaginas" and then returning it to the investor is anti-security and it is, I don't know, over the scandal actually." Scientist 10, an energy specialist, experience approximately 20 years.

- $\quad$ "Basically, it cannot be said that the policy is oriented gratuitously but there are some things that slightly worry. When reforming, it is not always viewed how it may result, let say, for Lithuanian energy and a target energy customer. For instance, the implementation of the Third Energy Package - I think it could have been implemented more rationally, without an attempt to implement it at the maximum and in the short term. For as long as Lithuania receives natural gas from only one source, there is no market, no real natural gas market." Scientist 11, an energy specialist, experience approximately 35 years.

- $\quad$ "It has probably been the first strategy, which was not even normally calculated nor assessed. This is just a mishmash of slogans, which was neither weighed in money nor in the impact on the costs or how it might result in national economy." Scientist 12, an economist, experience approximately 17 years.

When seeking energy security in society, it is not enough to create an individual world of intentions and rules, which seems meaningful only to its creators. There is an inevitable need to persuade society of its necessity and usefulness. In order to achieve this aim, a constant discussion is needed in which every aspect is reasoned with an aim to convince society and colleagues of

${ }^{22}$ The National Energy Independence Strategy, supra note 5. 
applicability, efficiency and the benefit of the project. Informants supported the government's efforts to rationalize energy policy and to seek for systematicity, but the opinions of scientists diverged because of the principles used in the process. Scientists have criticized the government's policy because of its insularity and its avoidance of public discussion, during which it could be possible to reach the most optimal decisions.

By providing particular examples (the circumstances of the Third Energy Package implementation; the significance of renovation of block households; debatable benefit of VNPP; development of renewable energy, etc.), scientists have shown that the avoidance of public discussion did not optimize the benefits of decisions. While analysing the scientific discourse it can be seen that the latter interpret the energy events, processes, and particular projects aimed at energy security improvement in a broader context, noting a more comprehensive view and able to identify the advantages, disadvantages and uncertainties of the latter. Scientific accuracy, rigour and rationality of arguments allow the development of scientific discourse with an attempt to create a valid alternative for political energy security discourse which predominates in the country.

\section{REPRESENTATION OF SCIENTIFIC ENERGY SECURITY DISCOURSE}

The establishment and development of each discourse creates conditions for conflict with other discourses, or even creates conditions for their elimination altogether. Scientific discourse not only competes and conflicts with others, but also it itself feels threatened by other emerging discourses. As previously mentioned, scientific discourse is being limited by institutionalized political discourse which, in many cases, ignores the application of scientific knowledge in real decision making and thereby limits the role of science in forming the overall energy discourse. It is therefore extremely important to talk about the efforts of representation and legitimation of the scientific energy security discourse. Despite the current unfavourable context for the empowerment of scientific discourse or the lack of institutional mechanism (which would integrate scientific knowledge into decisionmaking), scientific discourse can successfully compete. In order to gain legitimacy and convince the society of the necessity of scientific discourse, a significant role is given to supported (or not supported) public relations of discourse actors, actualising it and revealing its advantages.

When asked about personal participation in the public space, presenting the peculiarities of scientific energy security discourse, scientists provided different answers: 
- $\quad$ "Scientists do not usually fight own way in the media. Unfortunately, the good news is not interested in and is not relevant for the media." Scientist 1, an energy specialist, experience approximately 40 years.

- $\quad$ "Well, personally I have not tried really. However, there were several such attempts, when our study was introduced at the beginning of year, and at that time media's interest in our work suddenly increased, but it (interest) stopped quickly." Scientist 5, a mathematician, experience approximately 10 years.

- II explained energy security and, specifically, the advantages of construction of VNPP in various media channels (radio, television, newspapers, magazines, web sites, etc.)." Scientist 8, a political scientist, experience approximately 15 years.

- $\quad$ "I am not somehow directly related with that, except, there are all kinds of interviews with media representatives, or radio or television, or newspapers, it happens... <...>I attend conferences, in Lithuania and in various foreign countries, but personally I, as it is said, do not have any wish to climb "on the barrel." Scientist 11 , an energy specialist, experience approximately 35 years.

Many interviewed scientists mentioned a lack of the interest in scientific discourse from the outside. The informants mentioned examples of a rare interest of media, politicians and the society in hearing scientists' views. However, it is interesting that in spite of the perception of the importance and significance of scientific research, most scientists do not tend to take the lead in disseminating research results in public. In most cases, when asked about that, the informants expressed surprise at such a question and vividly answered, offering responses such as: "definitely not", "do not climb on barrel", we should not "tend to shout" or otherwise disseminate scientific arguments in the formation of energy security discourse.

The analysis shows that the scientific energy security discourse publicly is represented quite passively. The scientists lack faith in its success and its necessity need for society. Attempts to present scientific energy security discourse are sufficiently isolated and occasional. In most cases, the discourse representation is associated with the dissemination of research results, but their publicity is associated with scientific events leading to the fact that these results do not always become publicly known. However, as the majority of the informants noted, even in an attempt to publicize research findings in the field of energy, these efforts often face indifference in the media and society. If it happens that any aspect of the research is presented publicly, most often, according to the interviewed scientists, interest in the message is just one day; they do not feel consistent, permanent interest in scientific knowledge. The absence of systematic interest in energy research highlights the arbitrary nature of the relations between science and media 
(and perhaps society as a whole). Where does this arbitrariness come from? Perhaps it comes from the failure of scientists to establish understandable, attractive and arising curiosity for a society discourse; chronic public indifference to solid knowledge or universally matured scepticism and mistrust in science. At any rate, it remains unclear.

Reproduction of optimal and tangible alternatives, especially in the context of energy security, is not restricted only to affairs of the country, but every community or even an individual as well; it is a source of social, economic, and cultural (in this case, and energy) security. Alternatives in the energy security area reallocate risks, create a wide range of solutions, enable the need for negotiation and agreement, and reduce various possibilities for a narrow range interests' representation. Therefore, the role of science, as one of the most important and competent institution, is particularly important in this context. It is science and scientists that are associated with the disclosure of dangerous expressions of power, the identification of their penetration level into the energy policy and decision making. Critical thinking, confrontation with the governing bodies and the speaking boldly about the signs of power and their risks are typical social expectations from scientists, which, as the analysis show, due to different reasons are not always fulfilled by Lithuanian scientists.

\section{CONCLUSIONS}

As the accomplished analysis has shown, in Lithuanian energy security discourse it is difficult to succeed in converting scientific knowledge into power. Scientists who have vast knowledge, due to existing specific context and their own quite passive role(s), do not succeed in transforming that knowledge into power relations. Studies have shown ${ }^{23}$ that both scientists and politicians know the fundamental energy problems plaguing the country, their consequences, and also various strategies for their solutions, but they are not consistently and effectively implemented in practice due to the failure to find a constructive relationship between the represented discourses and agree on common goals. Emerging decision-makers' efforts to eliminate Lithuanian scientists from the formation of energy security discourse put them into an ambiguous situation in which it is difficult to expand expectations related with them.

After the examination of scientific discourse it is seen that scientists interpret the energy events in a broader context: when analyzing processes and specific

\footnotetext{
${ }^{23}$ Tomas Janeliūnas, supra note 4; Giedrius Česnakas, "Energy Security Challenges, Concepts and Controversy of Energy Nationalism in Lithuanian Energy Politics," Baltic Journal of Law and Politics 6:1 (2013) [forthcoming]; Dainius Genys and Eigintas Aleksandravičius, supra note 4.
} 
projects aimed at improving energy security, they can see a more complete picture and are able to identify strengths, weaknesses and uncertainties of the latter. It may be presumed that the discourse of scientists can help prevent the consequences of ineffective decisions if they are taken into account and relevant decisions are made. By providing concrete examples (about the implementation circumstances of the Third Energy Package; block household building renovation projects; the potential benefits of Visaginas NPP construction and so on), the scientists showed that the avoidance of public debate where scientific discourse could be enabled or the most effective arguments purified, did not lead to an optimization of decisions.

By summarising features of scientific energy security discourse it can be stated that the role of scientists in energy security discourse is not significant; institutional mechanisms for the use of scientific expertise in energy system development have not been created; the scientists are not included and they themselves do not rush to participate in the formation of energy security discourse. They relate the dissemination of scientific knowledge with publications in the scientific world. Scientific discourse could be associated with the attempt to create an alternative to the dominant political energy security discourse. It helps to create a more detailed and objective portrait of the country's energy system. Striving for accuracy helps scientists to avoid populism and to provide accurate and clear arguments, even though they do not always receive a response.

Two main strategies are used when seeking for greater power in the discourse formation process: manipulating the individual's position in the social space; transforming the categories and values of perception that form social reality. ${ }^{24}$ Neither strategy can be fully revealed due to the currently existing specific context in Lithuania. Firstly, scientists are not involved in the decision making and cannot fully compete with the other actors in the discourse, and thus assessing their own significance is a problem. Second, scientists do not sufficiently exploit a present credit of symbolic capital when providing society with scientific arguments and objectivizing the situation of energy security in such a way as to reinforce the interpretation of reality as they understand it.

\section{BIBLIOGRAPHY}

1. Adam, Barbara, and Joost Loon. "Repositioning Risk; the Challenge for Social Theory": 1-31. In: Barbara Adam, Ulrich Beck, and Joost Loon, eds. The Risk Society and Beyond. Sage Publications, 2005.

\footnotetext{
${ }^{24}$ Pierre Bourdieu, "Social Space and Symbolic Power". Sociological Theory. (1989): 14-25.
} 
2. Apklausa: VAI šalininku ir priešininku yra beveik po lygiai (Survey: VNPP Supporters and Opponents Are Almost Equal)) //

http://klaipeda.diena.It/naujienos/ekonomika/apklausa-vae-salininku-irpriesininku-yra-beveik-po-lygiai-428441\#axzz2AJ7Ld26A (accessed June 12, 2013).

3. Augutis, Juozas, Ričardas Krikštolaitis, Dainius Genys, and Giedrius Česnakas, eds. Lietuvos energetinis saugumas. Metinè apžvalga. 2011-2012 (Lithuanian Energy Security. Annual Review. 2011-2012.). Kaunas: Vytautas Magnus University, 2013.

4. Baločkaitè, Rasa, and Leonardas Rinkevičius. "Branduolinès energetikos diskursai Lietuvos žiniasklaidoje ir viešojoje nuomoneje: nuostatu takoskyros ir 'kalbančiuju klasès' formavimasis rizikos visuomeneje" ("Nuclear Power Discourse in Lithuanian Mass Media and Public Opinion: Attitudinal Divergences and the Emerging Talking and Acting Classes in the Risk Society"). Filosofija. Sociologija Vol. 20, No. 4 (2009): 259-270.

5. Balžekienè, Aistè. Socialinis branduolinès rizikos suvokimas: teorinès ižvalgos ir ju refleksija Lietuvos visuomenès požiūriuose i Ignalinos AE (Social Perception of Nuclear Risk: Theoretical Insights and its Reflection in Lithuanian Society Perception Towards Ignalina NPP). Ph.D. thesis. Kaunas: Kaunas University of Technology, 2006.

6. Beck, Ulrich. "Living in the World Risk Society." Economy and Society Vol. 35, No. 3 (2006): 329-345.

7. Bourdieu, Pierre. "Social Space and Symbolic Power." Sociological Theory Vol. 7, No. 1 (1989): 14-25.

8. Česnakas, Giedrius. "Energy Security Challenges, Concepts and Controversy of Energy Nationalism in Lithuanian Energy Politics." Baltic Journal of Law and Politics 6:1 (2013) [forthcoming].

9. Foucault, Michel. Diskurso tvarka (The Order of Discourse). Vilnius: Baltos lankos, 1998.

10. Foucault, Michel. Disciplinuoti ir bausti. Kalèjimo gimimas (To Discipline and to Punish: The Birth of the Prison). Vilnius: Baltos lankos, 1998.

11. Gaidys, Vladas, and Leonardas Rinkevičius. "Černobylio baimè, pigios energijos nauda ar kai kas daugiau? Dvidešimties metu visuomenès nuomonès apie Ignalinos AE sociologiniai tyrimai Lietuvoje" ("The Scares of Chernobyl, the Favoring of Cheap Energy or Something More? Twenty Years of Sociological Public Opinion Polls in Lithuania on the Ignalina Nuclear Power Plant"). Filosofija. Sociologija Vol. 19, No. 4 (2008): 102-111. 
12. Genys, Dainius, and Eigintas Aleksandravičius. "Bendro vardiklio beieškant Lietuvos energetinio saugumo orientyrai ekspertiniu požiūriu" ("Searching for Common Denominator - The Guidlines of Lithuania's Energy Security in Expert Point of View"). Politikos moksly almanachas No. 12 (2012): 63-84.

13. Janeliūnas, Tomas. "Lithuanian Energy Strategy and its Implications on Regional Cooperation": 190-222. In: Andris Sprūds and Toms Rostoks, eds. Energy: Pulling the Baltic Sea Region together or apart? Riga: Zinatne, 2009.

14. Lyotard, J. Francois. Postmodernus būvis (Postmodern State). Vilnius: Baltos lankos, 1993.

15. Molis, Arūnas. Lietuvos geoenergetinio saugumo politikos gairès ir Lietuvos geoenergetiniu alternatyvu paieškos trumpuoju ir vidutiniu laikotarpiu (The Guidelines of Lithuanian Geo-Energetic Security and Search for Lithuanian Geo-Energetic Alternatives in Short-term and Medium Periods). Vilnius: Centre for Strategic Studies, 2006.

16. Ministry of Energy of the Republic of Lithuania. The National Energy Independence Strategy. Vilnius, 2012.

17. Telešienè, Audronè. "Kritiškosios diskurso analizès metodologiniu principu taikymas sociologiniuose tyrimuose" ("Application of the Methodological Principles of Critical Discourse Analysis to Sociological Research"). Filosofija. Sociologija Vol. 16, No. 2 (2005): 1-6.

18. Van Dijk, Teun A. Discourse and Power. New York: Palgrave Macmillan, 2008.

19. Van Dijk, Teun A. "Discourse, Ideology and Context." Paper for the $7^{\text {th }}$ International Conference of Pragmatics. Budapest (July 2000). Folia Linguistica XXX/1-2 (2001): 11-40. 